\title{
USING ROLE PLAYING ACTIVITIES TO IMPROVE THAI EFL STUDENTS' ORAL ENGLISH COMMUNICATION SKILLS
}

\author{
Suchada Tipmontree \\ Prince of Songkla University \\ Asama Tasanameelarp* \\ Prince of Songkla University
}

\begin{abstract}
The purposes of this study were to examine the effects of using role playing activities to enhance students speaking skills as well as to investigate the usefulness of role playing activities in the development of selfconfidence in oral English. The experiment was conducted with an intact group of 50 Thai EFL undergraduate students. The data were collected by using (1) the pre-speaking test and the post-speaking test on oral competence in English communication, (2) the assessment form on students' self-confidence in speaking English, and (3) an interview form on students' opinion and self-confidence in speaking English before and at the end of the course. The research results revealed that role playing activities had positive effects both on student's oral competence and self-confidence in speaking English. The frequent practice over the period of time through the role playing activities is the vital key to enhance students' speaking abilities and improve their speaking confidence.
\end{abstract}

Keywords: role-playing, oral English communication skills, self-confidence in speaking English

Received: 31 January 2019

Accepted: 11 September 2020

\section{INTRODUCTION}

In language learning, communicating successfully in four macro language skills; listening, speaking, reading, and writing, is considered to be the main goal of teaching. According to Widdowson (1978) the basic language skills can be divided up into two groups. The first group is known as receptive skills consisting of listening and reading and the second group is productive skills which are based on speaking and writing skills. Among these, productive skills are thought to be the most problematic for EFL learners, especially speaking skills, due to the reason of lacking of opportunities to use English to communicate in daily lives (Shumin, 2002).

In this era of globalized world, the English language unquestionably has played an important role predominating over other countries and cultures, influencing all aspects of people lives, which paves the way for English to be a universal language that is used among global citizens for a

\footnotetext{
* Corresponding author: International College, Surat Thani Campus, Prince of Songkla University, 31 Moo 6, Makamtia District, Muang, Surat Thani, 84000, Thailand, Telephone: +6677355040. Email: asama.ta@psu.ac.th
} 
wide range of purposes from education, art, science to hospitality, industry, business, hospitality services, etc., all of which require a good command of English speaking skill.

Regarding Thai context, the major milestone of establishing the ASEAN Economic Community (AEC) has led to a growing awareness of development in Thai education, especially in English language teaching. Due to the reason of the free movement of labor amongst ASEAN member countries, the ability to communicate effectively in English is the initial concern as being the official language of the AEC community. To meet the demands and standards of global and ASEAN labor markets, a number of plans have been launched in all domains of every level of Thai education by the Ministry Education in order to achieve the goal of improving Thai students' English skills. At the higher education level which is the final stage of preparing students to compete and succeed in the global economy, many universities have reformed the English language syllabi and policies to strengthen their students' English ability.

However, even though there have been significant attempts to find the most sustainable interactive and effective methods in teaching so as to develop the English speaking skills of Thai students, it is seen that not all Thai students of English, although they have been studying English for many years, can communicate accurately, effectively and fluently. A survey carried out lately by an international language training company by means of data obtained from online English tests showed that English proficiency among Thais was the lowest in comparison with learners of English in other Asian countries (Noom-ura, 2013; Bruner, Shimray, \& Sinwongsuwat, 2014).

According to Tipmontree (2013), the lack of self-confidence is the main cause of low ability in English of Thai students due to the reasons of having limited knowledge of language usage and communication skills. Moreover, they are rarely provided with opportunities to practice speaking in the classroom because most of Thai EFL classrooms are traditional style of teacher-centered in which the teachers play important roles in the class by explaining the grammatical structures to the students and giving them exercises to practice and memorize the rules. As a result, the students can only recognize the grammatical rules but are unable to apply them into daily life communications (Tasanameelarp \& Laohawiriyanon, 2011). Therefore, it is important for teachers to use the right method that allows the students to actively participate in the classroom.

Communicative Language Teaching (CLT) approach has consequently been employed by many English teachers in order to encourage the students to be more active in the classroom, of which role-playing simulation is one of the most effective technics to improve students speaking ability because it provides large opportunities for them to communicate in English (Richards, 2005). Through role-playing simulation activities, not only can students' limited knowledge of language usage and communication skills be improved, but also they can gain more self-confidence in themselves when speaking.

Many studies have shown that there are noticeable effects of using role playing activities in ELT classrooms (Qing, 2011; Tipmontree, 2015) such as encouraging students to use their knowledge of English based on daily life situations, creating a friendly, supportive, and relaxing environment through which they can freely use their communication skills and build up sentence structures using appropriate vocabulary. Consequently, they can gain more self-confidence in speaking English which is one of the main obstacles in learning English. 
Due to the aforementioned benefits of using role playing activities, it is thought that role playing activities can be useful tools for Thai teachers to improve their students' oral English communication skills. Moreover, the recent research by Timontree (2015) examined the use of role playing in ELT classrooms and the research results showed that her participants were able to develop their speaking skills in all evaluated aspects. However, there have been few studies investigating the effects of using role playing on the improvement of self-confidence in English in Thai EFL classrooms. This research, therefore, aims to investigate whether or not role playing activities have effects on improving Thai university EFL students' oral communication skills as well as increasing their self-confidence in the classroom.

\section{RESEARCH QUESTIONS}

1. To what extent do role playing activities have effects on oral English performance of Thai university EFL students?

2. In what aspects do role playing activities contribute to the improvement of the oral English performance of Thai university EFL students?

3. Do role playing activities have effects on Thai university EFL students' self-confidence?

\section{METHODOLOGY}

\subsection{Participants}

In this one-group and pre-test post-test quasi-experimental research, the purposive sampling method was used to select the participants who were 50 third-year Thai EFL university students of a university in the South of Thailand. The ages of the participants ranged from 19 to 21 years old. All of whom had been studying English for over 15 years and they had never participated in any kinds of role playing activities in the classroom. They took English for Hospitality Services course at the university. The main reason of these students being selected is that because some previous studies that had been carried out through questionnaires with a number of employers showed that the graduated students had a very low competence in English communication (Tipmontree, 2015).

\subsection{Research Instruments}

\subsubsection{A proto-syllabus of English for Hospitality Services}

The syllabus composed of lesson plans, a compiled book as well as scenarios for everyday practice. There were seven chapters in the book which are as follows; Chapter 1 Flight Attendants, Chapter 2 Hotel Receptionists, Chapter 3 Restaurant Servers, Chapter 4 Sales Assistants, Chapter 5 Bank Tellers, Chapter 6 Tourist Police Officers, and Chapter 7 Patient Registrars.

In each chapter of the book, the topics are structured following the same format: (1) Vocabulary Preview, (2) Reading Practice, (3) Listening and Speaking Practice, (4) Writing Practice, (5) Travel Tips, and (6) Role Playing. The study was carried out over 15 weeks; 3 hours per week. 
Each chapter was taught for 2 weeks and students were given 1 week for preparation and practice before taking the test for communicative competence in oral English in real-life situations in the last week. Each class was started off by explaining the students how to study by using role playing activities and then the students were divided up into 7 groups. Each chapter consisted of 5 stages of teaching: preparation, practice, presentation, production, and discussion and evaluation.

\subsubsection{The pre-speaking test and the post-speaking test on oral competence in English communication}

The pre-test and the post-test were the same tests that contained seven role playing scenarios based on the topics in the book. Each scenario consisted of different situations that allowed the students to play out their own roles. In the first week of the semester, the pre-test was conducted in the classroom where each student was assigned to a role character. Then the students were asked to work in pairs. Each pair was given a five-minute period time of preparation before presenting their role playing in front of the three English lectures. As for the post-test, the process of conducting it was pretty much the same as the pre-test.

The validity of the tests was checked over by the three experienced English lecturers and were tried out with a group of fourth-year students who did not take part in the study. Then the feedbacks given by the experienced English lecturers were revised and created a final draft of the test that was used for the next step of the study. The students were scored through the rubric adapted from the study by Tipmontree (2015), according to which there were six features of communicative competence in hospitality services context respectively; Fluency, Giving Information, Selecting Language, Pronunciation, Confident Acting, and Problem Solving. A five-point Likert scale rubric ranging from one to five indicating the lowest to highest value was used in order to determine the effectiveness of the role playing technic.

\subsubsection{The assessment form on students' self-confidence in speaking English}

The research team used a set of assessment forms consisted of twelve items (measured by can-do ratings) in order to find out the students' self-confidence in speaking English. The students were asked to rate their speaking self-confidence level about several hospitality services communication contents such as on the flight, at reception in the hotel, at the restaurant, at the shopping plaza, at the deposits-withdrawals counter in the bank, at the tourist assistance center, and at the registration counter in the hospital.

\subsubsection{The interview form on students' opinion and self-confidence in speaking English}

After the students had performed their role playing, they were interviewed on the difficulties and problems they experienced while playing out their roles during the activities. The students' interview was employed in order to obtain in-depth information about two main issues; firstly, to know their opinions towards the usefulness of roleplaying activity and secondly, to investigate their self-confidence in speaking English before and after the treatment. A group of questions was set up as the framework and was conducted in Thai in order to gain as much information as possible. This session took approximately 10 minutes per participant. 


\subsection{Data Collection Procedure}

The data collection process began with a pre speaking test on oral competence in English communication administered before the English for Hospitality Services course had started. The teaching activities were conducted for a period of over 15 weeks consisting of 3 hours per week composed of seven chapters. Each lesson comprised the same teaching method covering the sequences of topics such as Vocabulary Preview, Reading Practice, Listening and Speaking Practice, Writing Practice, Travel Tips, and Role Playing. In the first week, the students were asked to form groups each of which consisted of seven or eight people, then the objectives of the research including how the process of role playing activities would be applied were carefully explained to them. This study compromised five stages of instruction through role playing activities all of which were adapted from the study by Tipmontree (2015). The sequences of teaching process were as follows

\subsubsection{Preparation stage}

In order to reach the maximum goal of oral communication in English. The course was introduced to the students for an hour, explaining them the course objectives. In order to help them produce the accurate language, the teacher taught them several topics such as vocabulary preview, listening and speaking as well as how to write each chapter.

\subsubsection{Practice stage}

The students were given various topics of Listening and Speaking through which they prepared themselves for the conversations related to each chapter. During this stage, the technic that was selected for the students to practice the conversations in pairs was the uncontrolled practice technique. At the end of the stage, the students were given feedback by the teacher which lasted an hour or so.

\subsubsection{Presentation stage}

The students were encouraged to work in groups so as to make up their own dialogues and stories in accordance with each scenario that the teacher had given. Throughout this stage, the students were encouraged to collaborate with each other, sharing their ideas to create the simulation of their own. During this stage, the teacher worked as a coach to guide and assist the students in case they needed support by the teacher.

\subsubsection{Production stage}

After the students were give the uncontrolled practice from the first week of each chapter teaching, they had to perform their own role playing in front of the classroom. In each chapter, each group performed a 20 -minuite role playing of 2 hours in total. The seven scenarios in which the students took part were as follows:

Scenario 1: On the flight, the flight attendant greets and checks a ticket as the passenger boards the plane, assists the passenger in finding his/her seat and stowing carry-on baggage, and explains the passenger how to use a seat belt and equipment. 
Scenario 2: At reception in the hotel, the hotel receptionist welcomes the guest, gives information on room rates and describes the rooms, and checks in the guest and deals with special requests from the guest.

Scenario 3: At the restaurant, the restaurant server greets the customer and escorts him/her to the seat, makes food recommendations upon request, and takes an order.

Scenario 4: At the shopping plaza, the sales assistant greets the customer and assists him/her to find the product he/she is looking for, gives advice and guidance on product selection to the customer, and notifies the customer of sales and special offers.

Scenario 5: At the deposits-withdrawals counter in the bank, the bank teller greets the customer, helps the customer fill the information in the withdrawal slip and processes cash withdrawals in the customer's checking account, and performs service when the customer checks the balance of his/her savings account.

Scenario 6: At the tourist assistance center, the tourist police officer greets the foreign tourist and offers help, asks for information about loss and robbery, and gives directions to the bank.

Scenario 7: At the registration counter in the hospital, the patient registrar greets the patient, processes patient registration, and collects the patient's medical record.

\subsubsection{Discussion and evaluation stage}

In this one-hour process of teaching, the students were asked to discuss about each chapter performance with the teacher. During this stage, the students were given feedbacks to encourage them for their performance. In order to do this, the students were told to take notes of their own performance to evaluate themselves, including their perceptions towards role playing activities.

In week 15th, the students were asked to get prepared for their group scenario, collaborating with each other in their own group to perform their role playing in real-life situations, which took place in week 16th at the real workplaces in a small tourist town in southern Thailand where the participants performed their role playing based on real-life situations, in week 16th, the students took the post speaking test on oral competence in English communication. Soon after the posttest had been carried out, the students were interviewed in order to obtain more detailed information on their attitudes towards learning through role playing activities.

\subsection{Data Analysis}

The scores obtained from the student's pre- and post-speaking tests on oral competence in English communication were analyzed through descriptive statistics, using The $t$-test for further quantitative data analysis, then the mean scores obtained from both pre and post tests were compared with one another as to whether or not role playing activities can be of assistance to university EFL students of English communication in improving their oral competence. Data obtained through the students' interviews were classified in accordance with themes and presented in percentage according to the students' attitudes towards their self-confidence before and after learning through role playing activities. 


\section{RESULTS AND DISCUSSION}

The findings are presented in two main sections - the students' speaking English achievement and the students' self-confidence after the English instruction delivered through the role playing techniques.

\subsection{The students' speaking English achievement}

To answer the first and second research questions asking whether role-playing activities affects the students' overall oral English performance, and to what extent role playing activities improve students oral English performance aspects of Confident Acting, Giving Information, Selecting Language, Pronunciation, Fluency, and Problem Solving, the results obtained from the students pre-and post-test scores were analyzed and compared using the paired sample t-test to determine the difference in improvement of the students' overall oral competence before and after the experiment which can be seen below.

Table 1: Overall Oral Competence of the Students before and after the Treatment

\begin{tabular}{ccccccc}
\hline \hline Test & Mean & S.D. & Speaking Ability & Mean Difference & t & Sig. \\
\hline pre-test & 1.85 & .475 & Low & 2.33 & $-26.248^{*}$ & \multirow{2}{*}{.000} \\
post-test & 4.18 & .521 & Excellent & & \\
\hline \hline
\end{tabular}

Note: *Significant at 0.05 level.

With respect to the data presented in Table 1, the post-test mean score of the participants is 4.18 , which is higher than the pre-test mean score, which is 1.85 . The result of the t-test mean score indicates a statistically difference $(\mathrm{t}=-26.248, \mathrm{p}<0.05)$.

It can be clearly seen from the overall post-test score which shows further development in speaking skills of the students after one semester of role playing activities treatment.

Table 2: Levels of Communicative Competence Aspects in

English before and after the Instruction

\begin{tabular}{|c|c|c|c|c|c|c|c|}
\hline Aspects & Test & Mean & S.D. & $\begin{array}{c}\text { Mean } \\
\text { Difference }\end{array}$ & $\begin{array}{c}\text { Effect } \\
\text { Size }\end{array}$ & $\mathbf{t}$ & Sig. \\
\hline \multirow{2}{*}{ Fluency } & pre-test & 1.92 & .752 & \multirow{2}{*}{2.28} & \multirow{2}{*}{3.05} & \multirow{2}{*}{$-16.998^{*}$} & \multirow{2}{*}{.000} \\
\hline & post-test & 4.20 & .728 & & & & \\
\hline \multirow{2}{*}{ Giving Information } & pre-test & 1.92 & .695 & \multirow{2}{*}{2.22} & \multirow{2}{*}{3.09} & \multirow{2}{*}{$-15.765^{*}$} & \multirow{2}{*}{.000} \\
\hline & post-test & 4.14 & .729 & & & & \\
\hline \multirow{2}{*}{ Selecting Language } & pre-test & 1.80 & .535 & \multirow{2}{*}{2.24} & \multirow{2}{*}{3.57} & \multirow{2}{*}{$-18.198 *$} & \multirow{2}{*}{.000} \\
\hline & post-test & 4.04 & .699 & & & & \\
\hline \multirow{2}{*}{ Pronunciation } & pre-test & 1.94 & .586 & \multirow{2}{*}{2.20} & \multirow{2}{*}{3.46} & \multirow{2}{*}{$-19.250 *$} & \multirow{2}{*}{.000} \\
\hline & post-test & 4.14 & .670 & & & & \\
\hline \multirow{2}{*}{ Confident Acting } & pre-test & 1.92 & .695 & \multirow{2}{*}{2.62} & \multirow{2}{*}{4.06} & \multirow{2}{*}{$-20.561 *$} & \multirow{2}{*}{.000} \\
\hline & post-test & 4.54 & .579 & & & & \\
\hline \multirow{2}{*}{ Problem Solving } & pre-test & 1.58 & .499 & \multirow{2}{*}{2.42} & \multirow{2}{*}{3.75} & \multirow{2}{*}{$-21.116^{*}$} & \multirow{2}{*}{.000} \\
\hline & post-test & 4.00 & .756 & & & & \\
\hline
\end{tabular}

Note: *Significant at 0.05 level. 
When further investigating into six aspects of oral communication, the students' oral competence improvement level of each aspect was significantly different as shown in Table 2 . When compared to the differences between the mean scores, it was found that Confident Acting was the most significantly improved among other aspects followed by Problem Solving, Selecting Language, Pronunciation, Giving Information, and Fluency, respectively. The findings show that role playing activities have a positive effect on improving all aspects of communicative competence of students.

Such results could be explained that role playing activities could help enhance students' speaking English abilities. As the activities provided the opportunities to the students to use their background knowledge that they previously learned to cooperatively work in their group in creating the scripts in order to interact with others in real life-like situations. Additionally, at the beginning of the training periods, the students faced lots of difficulties in performing their presentation due to many reasons; limitation of linguistic knowledge, low speaking confidence, and their first time of participation in role playing activities. Through the frequent practice of role playing activities with their group, the students were engaged in various of real-life situations based on the assigned characters which they can learn new linguistic forms and functions in hospitality services contexts contributed to the gradual improvement of their speaking performance. In line with, Jeffries (2005) and Mooradian (2008), this indicated the more frequently the students orally rehearsal with their peers in English, the better their speaking ability will be.

Moreover, as can be seen in Table 2, the degree of improvement of the participants' Confident Acting, Problem Solving, and Selecting Language appeared to be the most challenging to improve. This might be because of the students' reduction of nervousness. When they were familiar with the activities and they were freely to create the dialogues in non-threatening classroom environment, freedom to use language, they overcome their shyness and attempted to exchange their opinions with each other in order to present their role playing to other groups. This is consistent with the study by Tipmontree (2015) in which her participants claimed that the classroom atmosphere helped them gained more self-confidence in their use of English because all of them had to work in groups to make dialogues and regularly performed in front of the class which made them gradually increased their knowledge and use of English as well as their confidence in speaking.

\subsection{The students' self-confidence after the English instruction delivered through the role playing activities}

To answer the third research question asking whether role playing activities improve the students' self-confidence in speaking English, the data gained from the self-confidence assessment form on 14 hospitality services context situations and the interview were used to analyze the improvement of the students as shown below.

Table 3: Comparison of Students Self-Confidence in Speaking English 
before and after the Instruction

\begin{tabular}{lccccc}
\hline \hline \multicolumn{1}{c}{ Instruction } & $\overline{\mathbf{x}}$ & S.D. & Level of self-confidence & Mean Difference & Sig. \\
\hline Before & $\mathbf{2 . 7 1}$ & .800 & Medium & \multirow{2}{*}{1.31} & .000 \\
After & $\mathbf{4 . 0 2}$ & .604 & High & & \\
\hline \hline
\end{tabular}

Note: *Significant at 0.05 level.

After one-semester of participating in role playing activity, the mean scores from self-confidence assessment form before and after the treatment were compared, the results showed that the overall students' self-confidence level in speaking English improved significantly at the level of 0.05 . When considered each item of situation, it was found that the levels of self-confidence in speaking English of the given situations were at the medium level and after the treatment their self-confidence levels were at the high level in which the highest improvement from 14 hospitality services context situations was "I can check in the guest and deal with special requests from the guest." followed by "I can give advice and guidance on product selection to the customer."

It was consistently found from the interview data that role playing activities helped the student in improving their self-confidence in speaking English. Additionally, before taking part in the activities about $82 \%$ of the students reported that they had low confidence in speaking English but at the end of the study, about $90 \%$ of the students reported that they had self-confidence to communicate in English. Moreover, all of the students thought that the role playing activities helped them increase their self-confidence in oral English communication. Many students stated that in the first role playing task, they were scared to share their views with their peers due to lack of linguistic skills as well as confidence. However, after the regular rehearsal with their group which allowed them to express their views among each other and also to gain more knowledge from their friends, their self-confidence was noticeably increased, as one student mentioned that "In each role playing, we helped each other to create our group dialogue by sharing our opinions in the group which made us feel close to each other." And another student added "When we worked together, I learned many things such as the new expressions from my peers which I could use them in creating the dialogues."

Moreover, the learning through role playing activities made the lessons more interesting urging the students to actively participate in the activities, as student no. 30 said that "the lessons were not boring because we had to think and share opinions in the group to create our own situations." In addition, classroom atmosphere that encouraged the students to learn was one of the factors that also helped improving their confidence in speaking English. In this study, the students felt more confident in the strain-free environment, as one student reported that "In the classroom, I feel relaxed to express my views to the teacher and my peers in the classroom. And we can create our own dialogue by thinking about the situations that can be happened in the real-life.

\section{CONCLUSION}

To conclude, this current study has proved the effectiveness of role playing activities upon the improvement of the students' self-confidence in speaking English. According to Richard (2005) the frequently of communication practice through role playing activities plays the important role 
in developing students' speaking ability as well as their self-confidence in speaking. Moreover, it can be observed that the students in the current study learned how to collaboratively work in groups and how to strengthen their social bonding among each other during the interactions which are considered to be the vital and essential skills for the $21^{\text {st }}$ century.

There are however some issues that should be considered due to certain limitations. Hence, for further study some of the recommendations are given below.

1. As the sample size of the present study was limited to only 50 students in only one university, the further study should be replicated with a larger sample size from different universities in order to increase the generalizability of the findings.

2. In this study, a one-group pretest-posttest design was employed to examine the effectiveness of role playing activities on students' self-confidence in speaking English. In the next study, the retention test should be used to assess the students speaking skills in the long term.

3. In this study, six aspects of communication were involved in the speaking assessment. It would be beneficial if a subsequence study could be conducted focusing on the improvement of vocabulary and grammar.

\section{ACKNOWLEDGEMENT}

This paper is part of a study granted by Prince of Songkla University, grant no. LAM5603435. The authors would like to express special thanks to Mr. Tuna Girgin for taking his time to review and giving useful suggestions to improve this manuscript.

\section{REFERENCES}

Bruner, D., Shimray, Y. P., \& Sinwongsuwat, K. (2014). Thai Serbian A2 university EFL Learners' perspectives on learning and teaching oral English communication skills. In Proceedings of the 34th Thailand TESOL International Conference 2014: 21ST Century English Language Education: Towards Global Citizenship. The Empress Hotel, Chiang Mai, Thailand.

Jeffries, P. R. (2005). A framework for designing, implementing, and evaluating simulations used as teaching strategies in nursing. Nursing Education Perspectives, 26(2), 96-103.

Mooradian, J. (2008). Using simulated sessions to enhance clinical social work education. Journal of Social Work Education, 44(3), 21-35.

Noom-ura, S. (2013). English teaching problems in Thailand and Thai teachers' professional development needs. English Language Teaching, 6(11), 139-147. Retrieved from https://files.eric.ed.gov/fulltext/EJ1078705.pdf

Qing, X. (2011). Role-play an effective approach to developing overall communicative competence. Cross-Cultural Communication, 7(4), 36-39. doi: 10.3968/j.ccc.1923670020110704.317

Richards, J. C. (2005). Communicative language teaching today. Singapore: SEAMEO Regional Language Center. 
Shumin, K. (2002). Factors to Consider: Developing Adult EFL Students' Speaking Abilities. Methodology in Language Teaching. Cambridge: Cambridge University Press.

Tasanameelarp, A., \& Laohawiriyanon, C. (2011). Data-driven learning and low proficiency learners capacity for self-correction on grammar. NIDA Development Journal, 51(4), 105-129.

Tipmontree, S. (2013). Effectiveness of role playing in an English for Hospitality Services classroom. Surat Thani: Prince of Songkla University.

Tipmontree, S. (2015). Enhancing communicative competence through simulation in an EFL business English class. Asian EFL Journal, 17(4), 121-193.

Widdowson, H.G. (1978). Teaching language as communication. Oxford: Oxford University Press. 